\title{
스리랑카 개발포럼(2007) 회의 결과
}

2007년 스리랑카 개발포럼 회의가 Rajapaksa 대 통령 및 Amunugama 장관을 비롯한 각부장관 10 여명과 미국, 일본, 독일 등 주요 공여국 및 $\mathrm{UN}$, $\mathrm{ADB}$, 세계은행 등 국제기구 관계자 등 400여명이 참석한 가운데 1.29 (월)-30(화)간 주재국 Galle에 서 개최되었음.

\section{I . 회의 주요 내용}

\section{1. 개회식}

\section{가. Rajapaksa 대통령 연설요지}

- Rajapaksa 대통령은 LTTE의 문제 등으로 인 해 북부 및 동부주 피해복구가 상대적으로 지 체되기는 했으나 쓰나미 피해이후 주요원조국 및 국제기구의 도움으로 지난 2 년간 피해 복
구에 큰 진전이 있었다고 평가하면서 국제사 회의 지원에 사의를 표명함.

- 또한 동 대통령은 Mahinda Chinthana에 따 라 2006-2016간 스리랑카 중기개발 정책 목 표를 수립, 중소득국가(Middle income country)로 도약하기 위한 계획을 추진하고 있다면서 국제사회의 계속된 지원을 요청함.

- Rajapaksa 대통령은 테러방지 및 평화정착, 전력, 교통, 항만 등 인프라 개발, 농촌개발 등 지역간 불균형 해소, 지식기반경제구축 등에 노력하겠다고 주요 정책방향에 대해 설 명함

※ Mahinda Chinthana는 Rajapaksa 대통 령이 2005 대선시 공약한 스리랑카 중장 기 발전 비젼임. 


\section{나. 원조국 대표 연설 요지}

- Blake 미국대사는 미국정부가 쓰나미 피해 발 생후 교량, 항만, 보건, 교육분야에서 스리랑 카의 재건을 지원하였으며 스리랑카-LTTE간 평화협상에도 관심을 가지고 있다면서 평화적 수단에 의한 민족분쟁(ethnic conflict) 해결 방안으로서 민족간 권력공유(power sharing) 를 언급함.

- Jain 인도 외교부차관보는 인도가 남아시아 경제통합 강화와 남-남협력 차원에서 스리랑 카의 쓰나미 피해복구 뿐 아니라 무역, 투자 분야에서 파트너쉽 관계를 유지하고 있다고 설명하고 동부 Trincomalee에 5억불 규모의 발전소 투자협력 등 정치 · 경제적 협력을 강 화해 나가겠다고 하였음.

- 일본 외교부 경제협력국의 Takahashi 심의관 은 스리랑카의 지속가능한 개발을 위해서는 평화정착이 긴요하다고 하면서 일본이 경제지 원 뿐 아니라 스리랑카의 peace process를 위 해 지속적으로 협력해 나가겠다고 언급함.

\section{다. 국제기구 대표연설}

- Patel 세계은행 부총재는 그간 쓰나미 복구에 상당한 성과를 거두었으나 치안문제로 인한 동부 및 북부의 복구지연이 스리랑카 개발에
큰 장애가 되고 있다면서 Mahinda Chinthana 계획에 따라 지역간 격차, 도시농촌간 경제수준 격차 해소를 위해 노력할 필 요가 있다고 언급함.

- Lyons UN 스리랑카 사무소 대표는 스리랑카 의 천년개발목표(MDG) 달성을 위해 빈곤타 파, 재난방지 분야를 중심으로 계속적으로 지 원해 나갈 예정이며 인권보호와 평화정착 문 제에도 계속 관심을 기울이겠다고 하였으며, $\mathrm{ADB}$ 의 $\operatorname{Jin}$ 부총재도 스리랑카의 민족갈등으 로 인한 경제적 피해가 $\mathrm{GDP}$ 의 $4 \%$ 에 달하며 중소득 국가 진입을 위한 장애가 되고 있다고 언급함.

\section{2. 세션 1 : 정치 · 경제적 측면}

(Political Economy in Context)

\section{가. 발제 주요 내용}

\section{1) 스리랑카 경제현황(Jayasundera 재무기획 부차관)}

- GDP 성장률 : 1978 년 이래 최고의 성장률로 서 2007 년 $1 / 4$ 분기 $7.8 \%$ 기록

- 공공부채 : $\mathrm{GDP}$ 의 90\%로서 2004년 105\%에 서 감소 
- 석유수입(2006) : 2004년 석유 수입액의 두배 수준인 20 억불로서국가경제의 큰 부담

- 중장기성장계획

- 인프라개발

- 농촌개발

- 지식 기반 경제 추진

- 정치경제 이슈 해결노력 : 안보 - 평화구축, 국제경제 충격 완화 등

\section{2) 거시경제현황(Cabraal 중앙은행장)}

- 실업율(2006) : 최저수준인 $6.3 \%$ 기록

- 해외노동자 송금액(2006) : 23억불

- $\mathrm{FDI}(2006)$ : 5 억불을 최초로 초과함.

- 2007년 GDP 성장률 전망 : 7\% 이상 예상

- 거시경제과제 : 인플레이션 억제, 소득차별화 해소

3) 쓰나미 복구 현황(Abeygunawardena 재 무기획부 국장)

- 피해 복구 현황

- 주택 : 피해 가옥의 $51 \%$ 복구(남부 : $89 \%$, 북 부: $22 \%)$
- 생계회복 : 어업, 관광, 농경지복구가 각각 $70 \%, 90 \%, 84 \%$ 진행

- 보건 : 피해병원 및 피해학교의 각각 $23 \%$, $10 \%$ 복구

- 인프라 : 5 개 교량 복구가 진행중이며 18,000 가구의 전력공급이 재개

a 재건과정 문제점

- 건설비용 증가에 따른 재원 추가 소요, 민족 분쟁에 따른 북부 · 동부지역의 복구 지연, 재난복구 부처간 협조 미진, 복구성과 평가 및 재조정 메카니즘 부족

4) 치안 - 테러 문제(Rajapaksa 국방차관, De Silva 외교부 차관보)

- 스리랑카는 국가분열 방지 및 국민적 합의 형 성, 항구적 평화달성이란 측면에서 LTTE 문 제를 접근하고 있으며 테러리즘에 대해 단호 히 대처하고 있는 바, UN 등 국제사회도 스리 랑카 정부의 입장을 지지하고 있음.

- 스리랑카 군 · 경찰은 LTTE의 지속적 테러공 격에 대해 효과적으로 대응하고 있으며 민간 인 보호, 인권보호에 노력중

- LTTE는 2002년 이후 정전협정을 수없이 위 반해 왔음에도 스리랑카 정부는 LTTE와의 평 화회담 진전에 노력해왔으며 북부지역을 포함 
한 모든 스리랑카국민의 인권보호에 노력하고 있음.

\section{나. 참석자 토론 요지}

- IMF 대표는 스리랑카 거시경제 과제로서 인 플레 억제를 위한 통화관리 강화, 환율에 대한 중앙은행 개입 축소, 중장기 개발계획에 대한 민간분야의 참여 확대, 고용시장의 유연성 확 대를 언급함.

- 호주와 캐나다 대표는 지속가능한 개발을 위 해 평화회담 진전이 중요하다면서 스리랑카 정부가 NGO 등에서 제기하고 있는 인권보호 와 $\mathrm{NGO}$ 활동 지원문제에 보다 관심을 가져줄 것을 요청함.

\section{3. 세션 2 : 민족갈등, 재난방지, 인권문제}

\section{가. 발제 주요 내용}

- Samarasinghe 재난관리부장관은 스리랑카 가 상설 인권위원회 및 정부부처간 각종 인권 협의체를 설립하여 국제기구, $\mathrm{NGO}$, 원조국들 과 인권문제에 대해 긴밀히 협의하고 있다고 설명함.

- De Silva 검찰총장은 스리랑카가 1899년이래 불법적 구속을 금지하고 있으며 헌법에서도
고문금지, 불법적 구속 금지를 명시하고 있을 뿐 아니라 대법원과 인권위원회를 통해 일반 시민도 인권침해를 당했을 경우 이의제기 할 수 있도록 제도적 장치를 마련하고 있다고 소 개함.

- 북부 및 동부지역 피난민 인권보호 관련, Jayasinghe 국가건설부 차관은 피난민 (Internally Displaced People : IDP) 재정 착을 위해 주택 8 만호 건설, 보건.교육시설 재건, 인프라 확충을 추진하고 있으며, Jaffna 지역의 경우 LTTE의 공격 위험으로 Colombo-Jaffna간 주요도로인 A9 도로를 지난 8월 차단하기는 했으나 생필품, 식량 등을 해상로 등을 통해 계속 공급하였다고 설명함.

\section{나. 토론}

- 스위스, 노르웨이 대표는 북부 및 동부주에서 치안문제로 쓰나미 복구지원 NGO 들의 활동 이 제한되어 복구지원이 지연되는 문제점이 있는바 국제적십자사 및 $\mathrm{NGO}$ 의 활동에 대해 스리랑카 정부가 적극적으로 지원해 줄 것을 요청함.

- UNDP, 캐나다 대표도 북부 및 동부지역의 민 간인 보호, 인권보호 문제에 대해 스리랑카 정 부가 보다 관심을 기울여 줄 것을 촉구함 


\section{4. 세션 3 : 중장기 개발계획(Mahinda Chinthana)}

\section{가. 발제(Jayasundera 재무기획부 차관)}

- Jayasundera 차관은 지난 30년간 스리랑카 경제개발 노력의 뚜렷한 성과가 없음에 따라 실질적 경제성장을 위한 fast-track 정책으로 서 Mahinda Chinthana를 준비하게 되었으 며 향후 10 년동안 연 6-12\%의 성장을 목표로 하고 있다고 언급함.

- 또한, Mahinda Chinthana의 분야별 목표로 서 $\mathrm{GDP}$ 대비 5-7\% 공공투자달성, $\mathrm{FDI}$ 증진, 재정적자 및 공공부채적자 축소, 노동생산성 증진, 농촌개발 및 수익성 증대를 제시함.

\section{나. 토론}

- IMF 대표는 스리랑카 산업구조가 서비스 중 심이며 공공부채 수준이 타국에 비해 높은 문 제가 있으며 무엇보다도 인플레이션 억제가 중요과제라고 지적하고, 과도한 성장보다는 6-7\%의 성정정책을 추진할 것과 지속성장을 위한 투자증진, 노동생산성증진방안을 보다 관심을 기울일 필요가 있다고 언급함.

- $\mathrm{ADB}$ 대표는 전통농업분야의 생산성 증대가 어려운 점을 지적하였으며, 스위스 대표는 스
리랑카 중기계획 이행에 있어 고려해야 할 문 제로 부채 상환 부담, 부패문제, 민족갈등, 자 연재해 방지 대책 수립 등을 언급함.

\section{5. 세션 4 : 인프라 및 교육.보건}

\section{가. 발제 주요 내용}

\section{1) 도로(Amarasekara 고속도로부 차관)}

- 스리랑카의 도로는 대부분 50 여년전 건설되 어 노후되었으며 차량증가로 포화상태에 이르 었는 바, 쓰나미 피해도로 복구와 함께 고속도 로 건설, 국토확장, 지방도로 확충사업을 진행

- 주요 계획

- Colombo-Kandy간 고속도로를 비롯하여 5 개 고속도로 $600 \mathrm{~km}$ 건설을 추진

-국도 $150 \mathrm{~km}$ 를 4차선으로 확대하고, $5,000 \mathrm{~km}$ 를 2 차선으로 확대

- 지방도로 $6,000 \mathrm{~km}$ 를 복구 및 개선할 계획

\section{2) 항만 및 공항(Collure 항만-항공부 차관)}

- 콜롬보항 확충(ADB), Galle항 개선(JBIC), 함 반토타 항만개발(중국) 등을 위해 2016년까지 국제사회와 협력하여 항만시설을 지속적으로 확대 
- 반다라나야케 국제공항 확충 및 함반토타 국 제공항 건설을 2009 년까지 추진하고 open sky 협정체결 등 항공서비스 자유화도 아울러 진행

\section{3) 전력}

- 2016년까지 전력보급율을 96\%로 상향하는 것 을 목표로 Trincomalee 석탄화력발전소 등 전 력공급 확충 및 전력보급 효율성 제고에 노력

\section{4) 교육(Hewage 교육부차관)}

- 초등교육 및 중등교육 수준 향상, 교육시설 개 선, 학업부진 학생에 대한 대안학교 설립, 장 애학생에 대한 특수교육 확충, IT 교육확대, 영어교육 시설 증대 등을 중장기 교육정책 주 요 목표로 제시

\section{5) 보건(Kahandaliyanage 보건부 차관)}

- 북부.동부지역 및 농촌지역의 보건시설 확충, 보건분야에 대한 민간투자 유치 확대, 보건시 스템 개선을 위해 2009년까지 보건분야 지출 을 $\mathrm{GDP}$ 대비 $1.9 \%$ 에서 $2.5 \%$ 로 확대해 갈 예 정이라면서 국제사회의 계속된 지원을 요청

\section{나. 토론}

- $\mathrm{ADB}$ 대표는 인프라 분야에서 민간분야 투자 유치 확대를 위해서는 예측가능한 투자제도 유지가 중요하다고 하고 지방도로 개선, 신설 항구 건설과 관련 국제경쟁력 확보문제에도 관심을 기울일 필요가 있다고 언급

a 일본 대표는 지속적 경제개발을 위해 에너지 분야 개혁이 필요하다고 언급하였으며 $\mathrm{UNICEF}$ 대표는 북부 및 동부지역 교육시설 복구에 대한 스리랑카 정부의 관심과 지원을 요청함.

\section{6. 세션 5 : 원조}

\section{가. 국제사회의 원조 및 주요 원조사업 (Cooray 재무기획부 국장)}

1) 개요

- 2006년 해외원조액 규모 : 1,220 백만불(무상 : 195, 유상 1,025 백만불)

- 정부지출의 $17 \%, \mathrm{GDP}$ 의 $4.5 \%$ 규모

- 2007-2009년 해외 원조 예상액 : 45억불

- 2007 : 23억불, 2008 : 18억불, 2009 : 4억불 
2) 2007-2009 주요사업 계획(단위 : 백만불)

a 항만

- 콜롬보항 확장사업(300), 함반토타항 건설 (310), Oluvil항 사업(44) 등

- 도로 - 철도

- 콜롬보 외곽고속도로(185), 콜롬보 지역도로 망 2차 개선사업(150), 도로망 개선(150), 북 부 (Jaffna) 고 속 도 로 건 설 (250), Colombo-Katunayake 고속도로(200), Colombo-Matara 철도망 개선(100)

- 전력

- Kerawalapitiya 열병합 발전소(210), Jaffna 발전소(20), 북동부 송전선 확충(30) 등

- 상수도

- Jaffna(65), 네곰보(52), 콜롬보(50), II . 관찰 및 평가 Ampara(92) 등

- 교육

- 남동대학 개선(9), 니야가마 직훈 개선(9)

- 어업

- Dickovita항(60), 어업항만(21)

\section{나. 우리측 발언요지}

- 우리 대표단은 우리나라가 스리랑카 쓰나미 피해복구를 위해 41백만불의 유무상 원조를 지원하였으며 교량, 병원 등 분야에서 4 개 사 업을 남부주에서 진행하고 있다고 설명하고 앞으로도 Mahinda Chinthana 계획의 목표 달성 지원을 위해 인프라, 보건, 인적개발 분 야에 중점을 두어 스리랑카와 개발협력을 지 속해 나가겠다고 언급함.

- 또한, 북부주에서 진행하고 있는 Jaffna 기술 대학 개선사업 추진 과정에서 북부주 도로통 제로 인해 건축자재 수송에 어려움을 겪고 있 다고 하고, 조속한 사업 진행을 위해 스리랑카 정부가 지원하여 줄 것을 요청함.

- 금번 포럼에는 주재국 Rajapska 대통령과 주 요 각료들이 대거 참여하였는 바, 스리랑카측 은 동 포럼을 통해 2 년간의 쓰나미 복구진행 상황과 중장기 개발계획에 대해 주요 원조국 및 국제기구에 상세히 브리핑함으로써 스리랑 카의 쓰나미 복구와 중장기 개발에 대한 국제 사회의 계속된 관심환기 및 지원 모멘텀을 유 지하는데 상당한 성과를 거둔 것으로 관찰됨. 
- 그러나, 쓰나미 피해 발생직후 개최된 지난 1 차 회의에 비해 원조국들이 관심이 상대적으 로 저하된 것으로 보이며 동 포럼에서 새로운 지원계획을 발표한 국가 또는 국제기구는 없 었음(본부 고위인사가 참석한 국가는 인도와 일본뿐임)

- 또한 회의가 주요 이슈들에 대해 주요원조국 과 협의에 목적을 두기보다는 스리랑카 정부 의 개발목표와 정책에 대해 원조국에 설명하 는 형식으로 진행되어 원조국들의 참여도가 상대적으로 높지 않았음.

- 쓰나미 복구 과정에 대해서 스리랑카 정부와 원조국들 공히 상당한 성과가 있었다고 평가 하였으나 LTTE와 분쟁으로 인해 북부 및 동 부지역에 대한 복구가 지연되고 있다는데 인
식을 같이하였고, 유럽국가를 중심으로 원조 국 및 국제 $\mathrm{NGO}$ 에 활동에 대한 스리랑카 정 부의 지원확대와 스리랑카정부 - LTTE간 평 화회담의 진전을 위한 노력확대 필요성이 제 기 되었음.

- 스리랑카측은 동 포럼에서 향후 개발중점 분야로서 도로, 항만, 전력 등 인프라 분야 에 대해 국제사회가 적극적으로 지원해 줄 것을 요청하였는 바, 우리의 대스리랑카 유 상협력사업 선정시에도 인프라분야에 대한 지원을 우선적으로 검토해 나갈 필요가 있 는 것으로 사료됨.

[자료: 주스리랑카민주사회주의대사관] 